DOI https://doi.org/10.30525/978-9934-588-79-2-2.40

\title{
ОПТИМІЗАЦІЯ ВАНТАЖНИХ ПЕРЕВЕЗЕНЬ НА ТРАНСПОРТНІЙ МЕРЕЖІ ЗА ДОПОМОГОЮ ТАБЛИЧНОГО ПРОЦЕСОРА
}

\author{
Прокудін Г. С. \\ доктор технічних наук, професор, \\ завідувач кафедри міжнародних перевезень та митного контролю \\ Національного транспортного університету \\ Прокудін О. Г. \\ кандидат технічних наук, \\ доцент кафедри транспортного права та логістики \\ Національного транспортного університету \\ Хоботня Т. Г. \\ старший викладач кафедри міжнародних перевезень \\ та митного контролю \\ Національного транспортного університету \\ м. Київ, Украӥна
}

Більшість оптимізаційних задач на - це задачі про потоки у (network flow problems) [1]. Для задач фундаментальним є принцип збереження потоку в будь-якому [2], а саме:

сума потоків $F_{\text {вих }}(x)$ на виході вузла дорівнює = сумі потоків на його вході $F_{6 x}(x)+$ потенціал $p(x)$ вузла ( +пропозиція / попит).

Розглянемо розв'язання на транспортній мережі (TM) задачі, що найбільш часто зустрічається на практиці $[3,4]$, а саме мережевої транспортної задачі методом Вагнера Ш.М.

ТМ на рис. 1 взята з електронного атласу України у вигляді зваженого графа 38 вузлами і 24 дугами. Вона задана неорієнтованою мережею, де усі дуги неорієнтовані, що вдвічі збільшує розмір задачі, бо представляються вже не одною, а парою направлених назустріч о дуг $($ Київ $\rightarrow$ Коростень, Коростень $\rightarrow$ Київ). На ТМ присутні три різновиди вузлів:

- пункти-постачальники вантажу (вони зображені у вигляді квадратів);

- пункти-споживачі цього вантажу (вони зображені у виг-ляді кіл);

- транзитні пункти (вони зображені у вигляді овалів).

Обсяги поставок (зі знаком + ) і заявок вантажу (зі знаком -) проставлені поруч із кожним пунктом, а проставлена на кожній дузі дріб являє собою вартість перевезення одиниці вантажу (чисельник дробу) і пропускну здатність цієї дуги (знаменник дробу). Для спрощення 164 
сприйняття матеріалу значення вартості перевезення одиниці вантажу штучно отримані діленням відстані між відповідними транспортними вузлами на 100, а пропускні здатності дуг - діленням на 10 з наступним округленням до найближчого цілого.

Загальний обсяг пропозиції (поставок) у 40 одиниць деякого однорідного вантажу повністю дорівнює сумарному обсягу попиту (споживання), тобто ми маємо закриту транспортну задачу.

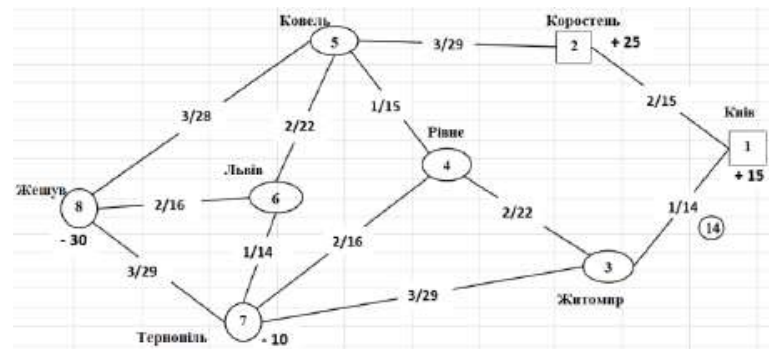

\section{Рис. 1. Графічне представлення мережевої транспортної задачі}

Спочатку у табл. 1 покажемо результати зведення вихідних даних ТМ до матричної форми. Для дуг тут відведені рядки, а для вершин стовпці. Пропускні здатності кожної дуги, так само як і вартості перевезення одиниці вантажу на ній, беремо безпосередньо з рис. 1. Там, де на мережі немає безпосереднього зв'язку між вершинами, передбачається їхнє блокування свідомо більшим числом - у таблиці 1 це 9. Відсутність петель у кожного транспортного вузла моделюється нулем.

Таблиця 1

Зведення мережевої задачі до матричної форми методом Вагнера

\begin{tabular}{|c|c|c|c|c|c|c|c|c|c|c|c|c|c|c|c|c|c|c|c|}
\hline Дуги & Пропускні & 1 & 2 & & & 5 & 6 & 7 & 8 & Дуги & Пропускні & & 2 & & 4 & 5 & 6 & & \\
\hline $1-2$ & 15 & 0 & 2 & 9 & 9 & 9 & 9 & 9 & 9 & $4-7$ & 16 & & 9 & 9 & 0 & 9 & 9 & 2 & 9 \\
\hline $2-1$ & 15 & 2 & 0 & 9 & 9 & 9 & 9 & 9 & 9 & $7-4$ & 16 & 9 & 9 & 9 & 2 & 9 & 9 & 0 & \\
\hline $1-3$ & 14 & 0 & 9 & $\underline{1}$ & 9 & 9 & 9 & 9 & 9 & $5-6$ & 22 & 9 & 9 & 9 & 9 & 0 & 2 & 9 & \\
\hline $3-1$ & $\overline{14}$ & 1 & 9 & 0 & 9 & 9 & 9 & 9 & 9 & $6-5$ & 22 & 9 & 9 & 9 & 9 & 2 & 0 & 9 & 9 \\
\hline $2-5$ & 29 & 9 & 0 & 9 & 9 & $\underline{3}$ & 9 & 9 & 9 & $5-8$ & 28 & 9 & 9 & 9 & 9 & 0 & 9 & 9 & 3 \\
\hline $5-2$ & 29 & 9 & 3 & 9 & 9 & 0 & 9 & 9 & 9 & $8-5$ & 28 & 9 & 9 & 9 & 9 & 3 & 9 & 9 & \\
\hline $3-4$ & 22 & \begin{tabular}{|l|}
9 \\
\end{tabular} & 9 & 0 & 2 & 9 & 9 & 9 & 9 & $6-7$ & 14 & 9 & 9 & 9 & 9 & 9 & 0 & 1 & \\
\hline $4-3$ & 22 & 9 & 9 & 2 & 0 & 9 & 9 & 9 & 9 & $7-6$ & 14 & 9 & 9 & 9 & 9 & \begin{tabular}{|l|}
9 \\
\end{tabular} & 1 & 0 & \\
\hline $3-7$ & 29 & 9 & 9 & 0 & 9 & 9 & 9 & $\underline{3}$ & 9 & $6-8$ & 16 & 9 & 9 & 9 & 9 & 9 & 0 & 9 & $\underline{2}$ \\
\hline $7-3$ & 29 & 9 & 9 & 3 & 9 & 9 & 9 & 0 & 9 & $8-6$ & 16 & 9 & 9 & 9 & 9 & 9 & 2 & 9 & 0 \\
\hline $4-5$ & 15 & 9 & 9 & 9 & 0 & 1 & 9 & 9 & 9 & $7-8$ & 29 & 9 & 9 & 9 & 9 & 9 & 9 & 0 & 3 \\
\hline $5-4$ & 15 & 9 & 9 & 9 & 1 & 0 & 9 & 9 & 9 & $8-7$ & 29 & 9 & 9 & 9 & 9 & 9 & 9 & & 0 \\
\hline
\end{tabular}


У нашому прикладі обсяги постачання дорівнюють пропускній здатності дуги, тобто $a_{i}=d_{i j}$. Обсяг споживання для виробляючих вершин $(1,2)$ мережі визначають за формулою: $b_{j}=\sum_{j \neq i} d_{i j}-a(x)$, (1)для вершин, які споживають вантаж $(7,8)$ за формулою:

$$
b_{j}=\sum_{j \neq i} d_{i j}+b(x),
$$

для транзитних вершин $(3,4,5,6)$ за формулою:

$$
b_{j}=\sum_{j \neq i} d_{i j} .
$$

Таким чином, для виробляючої вершини 1 обсяг споживання дорівнює $14+15-15=14$, для споживаючої вершини $8-28+16+29+$ $30=103$, а для транзитної вершини $6-22+16+14=52$.

На рис. 2 представлений результат розв'язання мережевої задачі у середовищі Excel, поданий у вигляді виділених знаком підкреслення значень. У клітинках з вартістю, рівною нулю (тобто для петель), потік є доповненням до пропускної здатності, тобто фіктивним.
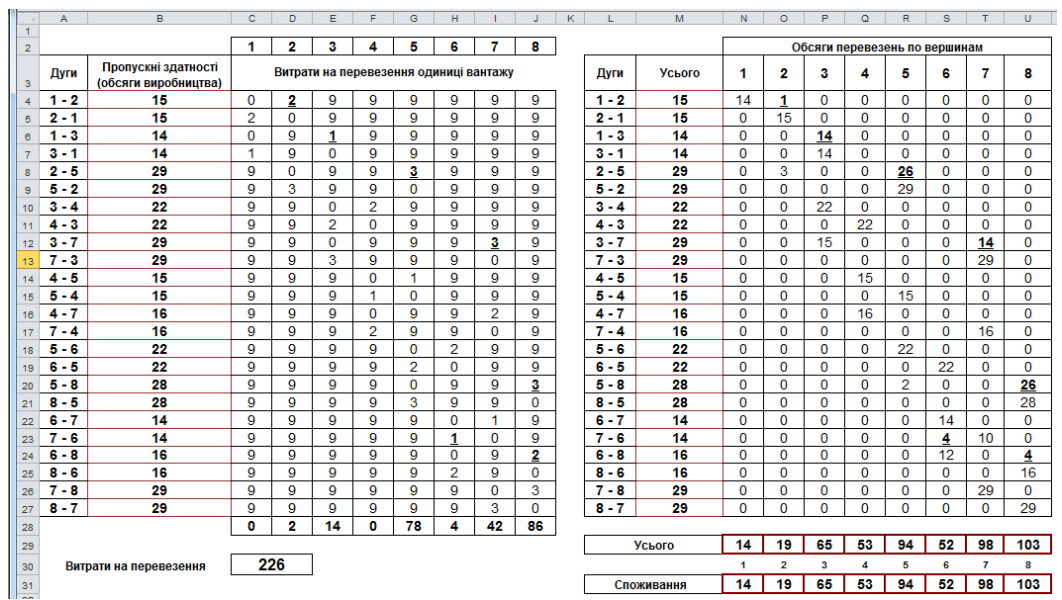

\section{Рис. 2. Розв'язання мережевої Т3 з обмеженнями на пропускні здатності за допомогою Excel-таблиці}

Графічне зображення оптимального плану перевезень вантажу представлено на рис. 3 . 


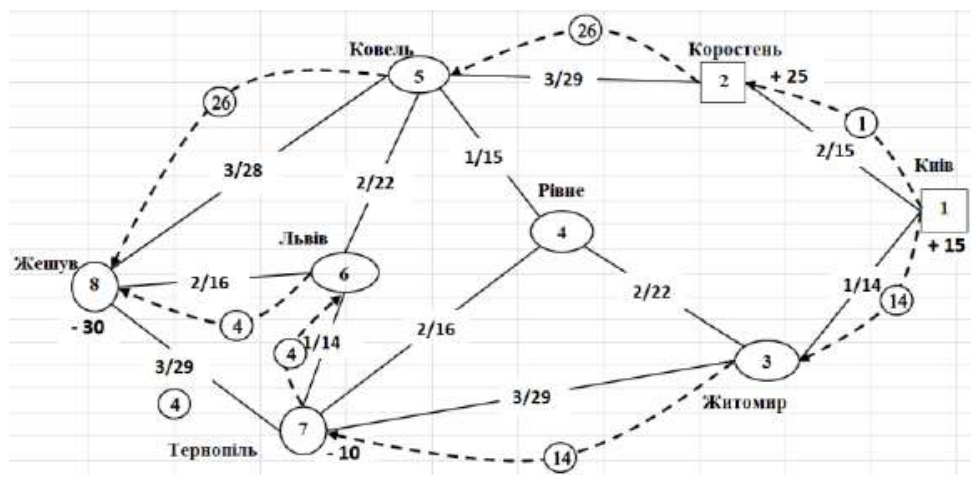

\section{Рис. 3. Оптимальні потоки у мережевій транспортній задачі}

У роботі описується один з підходів до рішення найбільш характерної для ТМ задачі знаходження оптимального плану перевезень вантажів у середовищі стандартного додатка Microsoft Office табличного процесора Excel, заснований на фундаментальному принциипі збереження потоку в будь-якому вузлу ТМ.

Однією $з$ переваг цього підходу $є$ його відносна простота й зручність роботи в табличному процесорі Excel. Стандартний інтерфейс, що властивий всім додаткам Microsoft Office, дозволяє без особливих зусиль вирішувати різні задачі на ТМ. До основних недоліків описаного підходу варто віднести його обмеженість на кількість змінних (до 200) при рішенні задач середньої й великої розмірності, що значною мірою звужує область його практичного застосування. Незважаючи на це, описаний підхід може бути ефективно використаний у навчальному процесі при розв'язанні транспортних задач невеликої розмірності, які представлені у мережевому вигляді.

\section{Література:}

1. Кузьмичов А.І., Медведєв М.Г. Математичне програмування в Excel: Навчальний посібник. 2005. 320 с.

2. Orden A. Survey of research on mathematical solutions of programming problems. Manag. Sci. 1965. 1(2). P. 170-172.

3. Prokudin, G., Chupaylenko, O., Dudnik, O., Omarov, D. Improvement of the Methods for Determining Optimal Characteristics of Transportation Networks. Eastern-European Journal of Enterprise Technologies. 2016. N. 6/3 (84). P. 54-61. DOI:10.15587/1729-4061.2016.85211. 
4. Prokudin, G., Chupaylenko, O., Dudnik, O., Svatko, V. Application of Information Technologies for the Optimization of Itinerary when Delivering Cargo by Automobile Transport. Eastern-European Journal of Enterprise Technologies. 2018. N. 2/3 (92). P. 51-59. DOI:10.15587/ 17294061.2018.128907, http://journals. uran. ua/eejet/ article/view/128907).

DOI https://doi.org/10.30525/978-9934-588-79-2-2.41

ФОРМУВАННЯ НЕЧІТКОЇ МОДЕЛІ ВИЗНАЧЕННЯ ПРИОРІТЕТУ ОБРОБКИ ВАГОНІВ НА СОРТУВАЛЬНИХ СТАНЦІЯХ НА ОСНОВІ АНАЛІЗУ ФАКТОРІВ ПОТОЧНОЇ ЗАТРИМКИ

Прохоров В. М.

кандидат технічних наук,

доцент кафедри управління експлуатаційною роботою

Українського державного університету залізничного транспорту

Калашнікова Т. Ю.

кандидат технічних наук,

доцент кафедри управління експлуатаційною роботою

Українського державного університету залізничного транспорту

Прокопов А. О.

аспірант кафедри управління експлуатаційною роботою

Українського державного університету залізничного транспорту

м. Харків, Украӥна

Проблема недотримання терміну доставки вантажів на Українській залізниці завжди була актуальною, але останнім часом іiї стан значно погіршився.

3 точки зору побудови моделі оцінювання можливості недотримання термінів доставки вантажів для вагонів, що проходять обробку на сортувальних станціях, найбільш технологічним є підхід, що використовує математичний апарат нечіткої логіки. Він надає можливість визначення величини пріоритету для кожного вагона на основі наявної інформації, уникнувши необхідності безпосереднього обчилення імовірностей. Адже обчислення величин імовірностей не $є$ ціллю такої моделі, а ціллю моделі $є$ визначення величини пріоритету. Однак ін- 